\title{
Process of local government fragmentation in Croatia: From a big-bang to a status quo
}

\begin{abstract}
The paper explores and explains the fragmentation process in Croatian local government during the transition period from 1990 onwards. Special focus is given to the emergence of new municipalities (municipal splits/ secessions) that occurred after the new two-tier local government system was established in 1993. Excessive fragmentation of territorial structure at the beginning of the 1990s was a systematic and centrally driven reform that was meant to break with the inherited local government model and break up its territorial structure as radically as possible. While the initial overhaul in 1993 was mostly the result of conscious policy implemented in a top-down manner, subsequent municipal splits were mostly the outcome of local initiatives and lobbying, and were predominantly shaped by local, primarily economic factors, whereas political and cultural factors were of secondary importance. The national institutional context, including criteria and procedural rules for splits, were quite liberal during this whole period with a moderate tightening-up trajectory. The number of municipalities finally stabilised in 2006 , since when there have been no more splits.
\end{abstract}

Keywords

Croatia $\cdot$ local government $\cdot$ municipal splits $\cdot$ territorial fragmentation

(C) University of Warsaw - Faculty of Geography and Regional Studies

Introduction

Contrary to prevailing trends in democracies of Western and Central Europe that have been consolidating their local government systems for decades, ex-socialist countries opted in many cases to fragment their local government territorial structure after the break-up of the old regime. Even among fellow countries in Central and Eastern Europe, Croatia stands out for the sheer scope of its local government territorial transformation during the period of transition. In only a few years after gaining independence in 1991, the number of municipalities more than quintupled. In relative terms, this constitutes the most radical case of local government fragmentation during a post-communist transition (Swianiewicz 2010; Baldersheim \& Rose 2010; Swianiewicz \& Gendźwił 2017). The focus of the paper is on the splits that happened after the initial "big-bang" of 1993 that was part of a complete redefinition of the local government concept and that was meant to be a clear sign of political departure from the previous system. The separations that followed the initial transformation are more easily observable and might reveal more concrete motivations and drivers that fuelled them. The fragmentation process in Croatia has not yet been thoroughly mapped nor subjected to an in-depth analysis and interpretation.

The goal of this paper is twofold: it seeks to analyse and explain both the process of fragmentation in Croatian local government in general and its variation among municipalities - individual cases of municipal splits. Therefore, analysis is structured along two intertwined research questions: 1: Which institutional and other contextual factors stimulated and facilitated fragmentation of the local government system? 2. Which local factors triggered individual secession initiatives? To understand

\author{
Mihovil Škarica \\ Faculty of Law, University of Zagreb, Croatia \\ e-mail: mihovil.skarica@pravohr \\ Received: 1 July 2020 \\ Accepted: 27 October 2020
}

these issues, the paper employs the explanatory framework developed by Erlingsson (2005) and adapted by Swianiewicz (2021), amending it with a couple of other contextual variables. The complementary influence of these factors contributed to a series of splits that happened between 1994 and 2006. To this day Croatia has been an exception among comparable countries by not having defined firm criteria and minimum population thresholds for the establishment of new municipalities (see: Swianiewicz 2021, Table 3). Therefore, all split initiatives have been heavily subjected to political arbitration and were materialised only when a balance between interests of local and national political actors was achieved. Understanding the explicit and underlying motivations of the actors involved, as well as the various institutional conditions that made the context favourable for secessions, might be useful in designing some future consolidation reform that would seek to avoid and prevent the negative effects of the large and centralised municipalities that provoked the aforementioned trends.

\section{Explanatory framework}

Contrary to amalgamation reforms that are often implemented forcefully and contrary to the will of the merging municipalities, fragmentation of territorial structure is predominantly bottom-up initiated. Still, without the favourable attitude of national political actors and a facilitating institutional and legal context, secession initiatives can hardly be successful. Secession initiatives emerge as a pursuit of the expected benefits of a fragmented local government. Such a territorial organisation has traditionally been advocated through several normative arguments, mostly 
pertaining to the issues of local democracy, but also to the allocative efficiency in delivering public services. Small communities have a tighter link between citizens and their representatives, which can result in easier control, and greater mutual trust and legitimacy. Small jurisdictions might be more accountable and responsive to the needs and preferences of the citizens and more easily provide opportunities for citizens' participation in public affairs. Additionally, small-sized municipalities may provide better access to local services and allow for their tailor-made delivery (Baldersheim \& Rose 2010; Swianiewicz 2010). However, the pursuit of these expected benefits is not universal, as secession initiatives emerge only in some municipalities and not in others. The local context that translates these arguments into impetus for secessions is therefore vital for understanding the emergence of secession initiatives. National governments might support municipal secessions for the same normative arguments, but their benevolent attitude towards fragmentation may also be shaped by their own gains, irrespective of potential negative effects on local government.

Arguably, all these elements are incorporated into Swianiewicz's proposed framework (2021). Following and adapting Erlingsson's model, which was developed for the understanding of municipal secessions in Sweden (2005), Swianiewicz integrates various variables into a single explanatory framework and employs both the analysis of institutional context of local government fragmentation and the examination of local conditions responsible for individual secession initiatives. The analysis of local drivers is based on three groups of economic, socio-cultural and political factors whose interplay may explain the pursuit of municipal independence. These factors almost always imply a certain heterogeneity within a municipality that produces centrifugal tendencies. Regarding economic factors, secession initiatives are expected to be more likely to emerge if there is a territorially defined part of a municipality that is richer, but not willing to subsidise poorer areas. The second line of economic reasoning presents secessions as a response to a feeling of being marginalised or exploited that can be developed in some parts of a municipality. Although the existence of this feeling and its relative importance for split decisions might be more precisely grasped only by a survey or a case study, it may be assumed to be real when indicated by several objective circumstances that increase the likelihood of it developing: great disparities in size between the "different" part and the rest of the municipality, peripheral location of a settlement and distance from the municipal centre or a situation of "no natural centre" in which no settlement is clearly dominant in terms of size. Cultural or identity issues constitute the second group of local drivers that implies socio-cultural differences within a municipality that can lead to its split. These differences usually arise in municipalities that incorporated culturally, linguistically or ethnically diverse areas; settlements that were historically administratively independent or those that are not connected by natural gravitational ties. The third group of factors relates to the political push for secessions. Political advocacy for secessions initiatives may be a mere articulation of the previously discussed factors by influential local political actors (officials of the existing municipality, politicians from the seceding part, national politicians interested in local issues for whatever reasons, citizens themselves), but it can also originate from a clear difference in political preference between different parts of a municipality, resulting in a quest for municipal independence.

Background: the evolution of local government territorial organisation 1945-93

During the first two decades of Yugoslavia (1945-63), local government territorial organisation was very unstable. Being vital for the realisation of "self-management" and "communal" concepts, local government was gradually subjected to a series of reforms that were usually quite drastic and often experimental in nature. The communal idea promoted large, self-sufficient municipalities, which were seen as the basis and primary entities for the political organisation of a society. Accordingly, the dynamics of local government territorial structure were unequivocally directed towards its consolidation. The number of basic local units in Croatia decreased constantly and substantially from 4.640 in 1945, through 737 in 1952 and 299 in 1955 , to 111 in 1963. In most cases amalgamations were forced in a top-down manner, fuelled by political considerations and without (formal) consultations with citizens. However, they were not spatially arbitrary: in most cases, amalgamated municipalities did gather interdependent gravitational areas of urban centres rather precisely so their borders successfully embedded existing functional areas into single administrative jurisdictions. At the end of the consolidation process in the mid-1960s, Croatia had the largest municipalities in Europe at the time, with an average size of more than 40,000 inhabitants. In the following period, the local government structure stabilised and the number of municipalities changed only sporadically due to individual cases of territorial adjustments, so on the eve of independence and the change of regime, Croatia was divided in 102 municipalities (Žuljić 2001; Pavić 2010; Koprić 2010).

A couple of years after the change of regime and independence from Yugoslavia in 1991, Croatia radically departed from both the concept and territorial organisation of local government inherited from the communist period. At the beginning of 1993, a two-tier system was established, with 487 municipalities (417 rural municipalities - općine and 70 urban municipalities/towns - gradovi) at the first level of local government, and 20 counties (županije) at the second level. This systemic change was mainly driven in a top-down manner and it cannot be perceived as a series of splits, but rather as a single and profound shift in the local government concept that was literally introduced overnight. Such an extreme fragmentation was the result of the harmonised and complementary considerations and goals of both national and local political actors. A universal and unifying goal was to detach as strongly as possible from the communist legacy, and municipalities - as "total" politicoadministrative entities - were perceived as embodiments of the old regime. From a central perspective, fragmentation was supported for several reasons: 1) to bring newly established democratic institutions closer to the people, i.e. to satisfy their "hunger for democracy"; 2) to enhance public participation in public affairs and interest in politics by multiplying the number of political positions; 3 ) to enable new political actors and parties to establish themselves at the grass-roots level; and 4) to prevent large and strong municipalities from becoming strongholds of political and ethnic opposition to central government, and to secure centralistic governance of the whole country in the context of war and transition. From a local perspective, it was argued that large municipalities seriously neglected their peripheral areas in terms of infrastructure, development and political voice. This led to mass migrations to municipal centres, which consequently caused demographic and economic devastation of municipalities' rural areas. Negative outcomes of "monocentric municipalism" made people "want to govern their own areas by themselves" (Malić \& Stiperski 1993). Furthermore, large municipalities became bureaucratised, non-responsive and alienated from citizens. Although these problems were partially mitigated by a rather strong position and extensive role of sub-municipal government before 1990 (in housing, maintenance and improvement of public space and infrastructure, etc.), the will to dissolve these structures prevailed. In the context of war, occupation and 
MISCELLANEA GEOGRAPHICA - REGIONAL STUDIES ON DEVELOPMENT

Vol. 25 • No. 1 - 2021 • pp. 46-53 • ISSN: 2084-6118 • DOI: 10.2478/mgrsd-2020-0043

Table 1. Timeline and number of municipal secessions in Croatia

\begin{tabular}{|c|c|c|c|c|c|c|c|c|c|c|c|}
\hline Year & 1993 & 1994 & 1995 & 1997 & 1998 & 1999 & 2000 & 2001 & 2002 & 2003 & 2006 \\
\hline Number of splits & - & 1 & 1 & 49 & 4 & 2 & 1 & 1 & 1 & 2 & 6 \\
\hline $\begin{array}{c}\text { Number of } \\
\text { municipalities } \\
\text { established }\end{array}$ & - & 1 & 10 & 52 & 4 & 2 & 1 & 1 & 1 & 2 & 6 \\
\hline $\begin{array}{c}\text { Total number of } \\
\text { municipalities }\end{array}$ & 487 & 488 & 498 & 539 & 543 & 545 & 546 & 547 & 548 & 550 & 556 \\
\hline
\end{tabular}

Source: Author

economic transition, with all their side-effects, this kind of local government overhaul met no resistance or serious opposition. The described reform of the local government system was announced much earlier than it was finally introduced: the new constitution adopted and proclaimed at the end of 1990 explicitly envisaged (rural) municipalities, towns and counties as building blocks for a new local government system. Legislative implementation of constitutional provisions was delayed because of the war. Although there was a wide consensus about the rationale for the radical departure from the inherited institutions, reformers did not have a clear vision about the exact number of new municipalities, and the criteria for their establishment were not set beforehand. Such a situation offered a fertile ground for a two-year process of negotiations between relevant actors, bottom-up lobbying, political patronage and arbitration that shaped the new system's number of municipalities and counties. The lack of criteria for establishing new municipalities was evident from the get-go - population disparities between the largest and smallest municipalities were enormous. On average, one old municipality dissolved into five new ones, but there were cases of more extreme fragmentation - e.g. the municipality of Čakovec split into 18 smaller municipalities. At the same time, seven old municipalities continued to exist without splitting.

Territorial changes in 1994-2006: chronology and basic facts

In the years following the big break of 1993, the territorial organisation of Croatian local government continued to reshuffle, mostly incrementally. All cases of municipal secessions in the post-1993 period took place between 1994 and 2006, with one major wave of splits in 1997, two minor waves in 1995 and 2006 and several individual splits in-between (Table 1). ${ }^{1}$ Simultaneously with the 1997 wave of splits, 13 cases of municipal mergers occurred. After the territorial dynamics settled down, Croatia reached the current numbers of 128 urban and 428 rural municipalities, with the overall mean population of 7,706 and a median of 2,983 as of now. In total, there were 68 instances of municipal splits, resulting in 80 new municipalities. Although all newly established local government units were arguably founded as rural municipalities (općine), their total number increased only slightly (from 417 to 429 ). This is because, in parallel, the status of 58 rural municipalities founded in 1993 was subsequently changed and they were labelled as towns. ${ }^{2}$

In four cases, municipal splits resulted in more than one additional municipality, the most interesting being the case of Zagreb in 1995, when ten surrounding municipalities seceded from the city urban core. Unlike other splits, this case was only one in a series of administrative reshufflings that were performed on Zagreb and its surroundings in the period before and after independence. Municipalities that seceded from Zagreb in 1995 had been merged with the city as late as 1990 . Since the merger had been done without any consultation with local institution or population and without historical precedent, these splits came as no surprise as they more or less re-affirmed the administrative boundaries that Zagreb had had before 1990 (Hrženjak 2000; Ivanišević 2000).

Not all newly established municipalities emerged from a single existing municipality - there were four cases of settlements being extracted from two existing municipalities. Six municipalities were split on more than one occasion in different years. All newly established municipalities, except two bigger towns that separated from Zagreb (Velika Gorica and Zaprešić), had significantly smaller populations than the current national mean. Furthermore, the vast majority of them $(87 \%)$ were even smaller than the national median. Fourteen of them (17\%) had a population below 1,000 , which is a significantly bigger share of such municipalities than in the total population (6\%). The population categories of new municipalities are presented in Table 2.

The political, institutional and legal context of the fragmentation process

Municipal splits in the post-1993 period were not a mere continuation of previous systemic change, although they were certainly inspired by it. The initial positive effects of the previous fragmentation had outnumbered the negative - new municipalities managed to improve their basic infrastructure, and subsequent split initiatives certainly looked up to these positive examples. Also, after the big reform of 1993 that was implemented arbitrarily and without any (firm) criteria for the establishment of new municipalities, central government lost the moral grounds to prevent and deny further splits. The majority of splits in 1997 and later occurred in new municipalities - those that had been established in 1993 (51 cases) - and only a small portion of them implied (belated) secession from the old municipal centre (17 cases). Therefore, the reasons that led to the initial "big-bang" that were analysed previously are not automatically applicable to these later splits, nor sufficient to explain them. There are three groups of explanatory factors that shaped the institutional context favourable to stimulating secession initiatives and facilitative of their success: a) the legal framework for the establishment of new municipalities (criteria and procedure); b) the overall institutional position of local government within the politico-administrative system; and c) the political climate and considerations of influential political actors. The following paragraphs analyse each of these groups.

1. The territorial organisation of local government in Croatia has been a matter of an organic law that defines the number of municipalities and territorial reach of each. Therefore, every intervention in local government territorial structure requires a legislative procedure in the national parliament. General 
Table 2. Population categories of new municipalities

\begin{tabular}{|c|c|c|c|c|c|}
\hline Population & $<\mathbf{1 , 0 0 0}$ & $\mathbf{1 - 2 , 0 0 0}$ & $\mathbf{2 - 3 , 0 0 0}$ & $\mathbf{3 - 5 , 0 0 0}$ & $\mathbf{> 5 , 0 0 0}$ \\
\hline Number of municipalities & 14 & 31 & 25 & 6 & 4 \\
\hline Share of new municipalities & $17.5 \%$ & $38.8 \%$ & $31.2 \%$ & $7.5 \%$ & $5 \%$ \\
\hline
\end{tabular}

Source: Author

legislation on local government (Local and Regional Government Act) provides basic definitions of municipalities, but they are worded in a manner that leaves the establishment of new municipalities completely to the discretion of the parliamentary majority. These provisions do not require any specific conditions to be met by a new municipality - there is no minimum population threshold or any other firm applicable criteria. The initial rules of the procedure for the establishment of new municipalities, set in 1993, were rather liberal and simple, but also ambiguous. However, each of the subsequent changes (in 1997 and in 2006) inserted certain procedural elements that gradually tightened up the rules for splits. Possible initiators were determined in the same way throughout whole period: secession can be initiated by either the municipal council or by at least one third of residents in any settlement that wants to secede. In practice, all splits were formally initiated by the citizens, often contrary to the will of the council. In 1993-97 these were the only provisions regulating the splits (except the formal opinion of the council to be submitted when citizens are initiators), as consultations with citizens were only optional. In 1997, consultations with residents became mandatory only if the council was the initiator, and only in 2006 did they become mandatory for all proposals. Additional conditions for valid proposals were added in 1997: formal opinions of both the municipal council and the county assembly were required (not necessarily positive), ${ }^{3}$ but also an explicit formal approval from the Ministry of Finance. ${ }^{4}$ Since 2006, this approval was "upgraded" - it needs to be issued by the government cabinet and, since then, proposals for splits cannot bypass the cabinet and materialise without its explicit consent. Although the wording of the provision requiring consultations is not unambiguous, practice established a rule that the only people participating in consultations are those residing in the area that wants to secede. The form of these consultations is not prescribed, and it is completely left to the initiators to organise them. As was shown in practice, consultations can be substituted by (or conducted in the form of) the initiative itself, especially if it is signed by the overwhelming majority of residents. These proposals cannot be submitted to parliamentary legislative procedure directly by initiators. Formal legislative proposals can only be submitted by the cabinet or by members of parliament, individually or collectively. The requirement of explicit and formal cabinet consent to the proposal made new splits initiated via members of parliament practically impossible. ${ }^{5}$ Even when all procedural rules were followed, the split is not guaranteed - the final decision on proposed changes is still left to an autonomous and discretionary decision of the parliament. In the final round of

\footnotetext{
${ }^{3}$ Although their consent is not required, these institutions could oppose such proposals most effectively by ignoring them, thus freezing any further procedure. Because of this, some of the split proposals were instigated even without these formal opinions (Hrvatski Sabor, 2005).

${ }^{4}$ Initiators were obliged to enclose a projection of expenditures of future municipality and adequate sources of revenue to cover them.

${ }^{5}$ This is problematic from the constitutional point of view, but it has not been officially addressed by the Constitutional Court. Such provision limits the constitutional role of parliament as the sole legislator who should be able to act independently from the cabinet as the executive institution.
}

secessions in 2006, there were nine splits officially proposed by the cabinet, but only six of them were realised (Hrvatski Sabor 2005).

2. The second wave of secessions in 1997 and following cases were heavily facilitated by the overall position of local government in the politico-administrative system. Such a position is predominantly indicated by the distribution of public functions among territorial levels (the functional aspect) and the fiscal regime of the local government (the financial aspect). The main purpose of local government was still a political one: to bring democratic institutions closer to the people and to engage them in the political process, while administrative and service-providing roles were secondary. Prior to 1993, arguably all local public affairs were performed by municipalities. From that year on, these tasks were distributed among newly established municipalities, counties, and a dense network of branch offices of state administration and other central public institutions. During the 1990s, Croatia was a heavily centralised and hierarchically governed country. In 1999, local government expenditure comprised only $6.5 \%$ of total public spending. Being relieved of many administrative and service-providing responsibilities, municipalities neglected capacity and efficiency considerations. In such a context, villages and small towns could "afford" secession and be on their own. The question of sufficient resources was rarely raised, as municipalities were not expected to do much - complex and expensive public services (healthcare, education, social welfare, fire protection) were the responsibility either of counties or of the central state. Even exclusively municipal services were not much of a concern. Those of economic nature (water services, collection of municipal waste, public transport) were in most cases delivered by companies that are formally inter-municipal, but effectively under the control of a bigger urban municipality in the area - usually an ex-municipal centre (Škarica \& Giljević 2016). From 2000 onwards, the functional scope of local government was expanded, as decentralisation policies were implemented in the fields of education, social care, healthcare and fire protection. Although mostly limited to the counties and urban municipalities, this decentralisation coincided with the decrease in secession initiatives that has been seen since the beginning of the century.

Besides functional aspects, the financial context of local government also facilitated pursuits of municipal independence. In the second half of the 1990s, unconditional transfers (state aid) from national to local budgets comprised $8 \%$ of total local government revenue, this share being much bigger for rural municipalities (20\%). Existing schemes of financial assistance to smaller and rural municipalities (the vast majority of seceded municipalities) provided a safety cushion to splitting settlements, thus reducing risks of a split - in a situation of financial deprivation they could count on additional resources. At the same time, personal income tax was the main source of local governments' own revenue, belonging to the municipality of residence of the employee. Thereby, a seceding municipality could count on preserving its whole fiscal capacity no matter where jobs and businesses were located.

${ }^{6}$ All financial indicators are drawn from the annual financial reports of local government units compiled and published by the Ministry of Finance. 
MISCELLANEA GEOGRAPHICA - REGIONAL STUDIES ON DEVELOPMENT

Vol. 25 • No. 1 - 2021 • pp. 46-53 • ISSN: 2084-6118 • DOI: 10.2478/mgrsd-2020-0043

Table 3. Ratio of per capita expenditure between new and abandoned municipalities ${ }^{6}$

\begin{tabular}{|c|c|c|c|c|}
\hline Ratio new/abandoned & $<\mathbf{0 . 5}$ & $\mathbf{0 . 5 - 1}$ & $\mathbf{1 - 2}$ & $\mathbf{> 2}$ \\
\hline Number of municipalities & 9 & 28 & 20 & 9 \\
\hline Share of municipalities & $13.6 \%$ & $42.5 \%$ & $30.3 \%$ & $13.6 \%$ \\
\hline
\end{tabular}

Source: Author

Another feature of the local government institutional context provoked municipal splits - the weak position of sub-municipal government institutions. In this period, sub-municipal government was completely marginalised and deprived of legal subjectivity, competences and finances. Such an institution could not serve its basic purpose - to articulate and to promote the interests and needs of individual settlements within municipalities. In this context, sometimes the only viable option for marginalised settlements was to establish their own municipality.

3. Democratic considerations and the predominantly (symbolic) political role of local government during this period were compatible with the political interests of major political actors. Despite justifying secessions by citing "the right of self-government" and "honouring the will of the citizens", the attitude of ruling parties towards splits was primarily shaped by political gains: the more municipalities there were, the more political seats there were to win. At the same time, a fragmented local government structure could secure the continuation of a centralised governance model and help to preserve political power within the hands of national political elites. The vast majority of splits occurred during the terms of centre-right governments led by the conservative Croatian democratic union (Hrvatska demokratska zajednica - HDZ) who were in power in 1990-99 and 2004-11. Small and rural areas, due to their conservatism, have traditionally been their strongholds. This was confirmed in arguably all cycles of local elections, especially during the 1990s. In the 1997 elections, HDZ was the most successful party in more than $70 \%$ of municipalities. Only a handful of secessions took place during the tenure of the centre-left government lead by the Social-democratic party (SDP) in 2000-03. This was the only government that explicitly announced it would not allow further local government fragmentation, although it did not intervene in relevant legislative framework during that period. Still, five splits happened during their term, but they were sponsored by individual members of parliament and adopted even with explicit opposition from the ruling government. It seems that both of the ruling parties at the national level favoured secessions in municipalities under their political control. Among 58 cases of splits that occurred during the terms of HDZ governments (resulting in 61 new municipalities), in 48 of abandoned municipalities (83\%) HDZ won the subsequent local elections, as well as in 45 new municipalities $(74 \%)$. Out of five splits under the SDP rule, in four new municipalities subsequent local elections in 2005 were won by a party from the national ruling coalition.

\section{Local drivers of municipal secessions}

Municipal secessions can be either facilitated or hampered by the national institutional context, but they are primarily pushed by a complex interplay of various local factors. This section follows the proposed framework of Swianiewicz (2021) and summarises a multitude of local factors and their possible indicators in three distinctive groups - economic, cultural and political. It examines the influence of all the proposed indicators on which data were obtainable by desk research. The following analysis deals with 63 cases of municipal splits, which resulted in 66 newly established municipalities ${ }^{7}$ - the cases of the Zagreb secessions and the four two-parented splits are left out, due to specificities which cannot be easily embedded into the proposed framework.

1. In general, most of the splits occurred in economically deprived areas. Only 13 pre-split municipalities (20\%) had per capita budgetary expenditures above the national average in the year of the split. This suggests that economic reasoning, however conceptualised and indicated, played a decisive role in pursuing secession strategies. Because of the generally low financial strength of the municipalities involved, the "secession of the rich" argument must be taken cum grano salis - in most cases, the "rich" seceding part only means "richer than the remaining part". However, this relation is confirmed in fewer than half of cases. In total, 29 new municipalities (44\%) had bigger per capita expenditure than their former partners. The distribution of this ratio is shown in Table 3. There is a clear distinction in this regard between municipalities that separated from an old municipal centre and those that split from recently formed municipalities. Out of 19 cases belonging to the first group, in only five (26\%) was the seceded part richer than the remaining one. In the latter group, which gathers structurally more similar municipalities, secession of the richer part comprises more than half of cases $(24 / 47-51 \%)$. In any case, financial differences between new and abandoned municipalities were not so extreme - in only 18 cases was difference in per capita expenditure between new and abandoned municipalities more than double.

Another line of economic argumentation follows the subjective feeling of a "different part" in a municipality being marginalised or exploited. As was previously discussed, this feeling may be developed under various circumstances of structural differences between the seceding and remaining part of a municipality. Regarding difference in population size between new and abandoned municipalities, almost half of the Croatian cases of splits belong to the "even-steven" category, according to Swianiewicz's proposed typology (2021), while remaining cases are almost equally distributed between "grown-up leaving the nest" and "nestling leaving the nest" groups (see Table 4). There were even nine cases in which a seceding municipality had a bigger population than the abandoned one, but not by much, so these cases are classified into the "even-steven" category. Mean population size ratio between the abandoned and new municipalities is 4.6.

As with previously discussed financial indicators, there is a clear dividing line between municipalities that seceded from the old centres and those that split from municipalities established in 1993. The mean population size ratio between municipalities in the first group is 10.1 , while in the latter case it is only 2.3 . Fifteen of 19 municipal splits within the first category resulted in the establishment of "nestlings" - municipalities smaller than one fifth the size of the abandoned one - which constitutes $88 \%$ of all such cases. Conversely, out of 47 secessions in the second group, 31 were "even-steven" cases (all such cases are from this

${ }^{7}$ In three cases, two municipalities seceded at the same time from the abandoned one. 
Table 4. Population size of new municipalities in relation to the abandoned

\begin{tabular}{|c|c|c|c|}
\hline Population size ratio & $\begin{array}{c}<\mathbf{2} \times \\
\text { Even-steven }\end{array}$ & $\begin{array}{c}\mathbf{2 - 5 \times} \\
\text { Grown-up leaving the nest }\end{array}$ & $\begin{array}{c}\boldsymbol{> 5 \times} \\
\text { Nestling leaving the nest }\end{array}$ \\
\hline Number of municipalities & 31 & 18 & 17 \\
\hline Share of total splits & $47 \%$ & $27 \%$ & $26 \%$ \\
\hline
\end{tabular}

Source: Author

group of municipalities), 12 are "grown-ups leaving the nest", and only four represent cases of nestlings. Marginalisation of "nestlings" does not stem only from their smaller size, but also from the fact that these cases of splits occurred in spatially large municipalities in which a sense of marginalisation in peripheral parts was more easily developed. Pre-split municipalities that nestlings seceded from have an average area much larger (125 $\mathrm{km}^{2}$ ) than both the national average before 1997 splits $\left(114 \mathrm{~km}^{2}\right)$ and the current one $\left(102 \mathrm{~km}^{2}\right)$. A large number of even-steven cases shows that territorial reform in 1993 produced many municipalities with no natural centre. Settlements of similar size have found themselves in centre-periphery and superiorsubordinate relations never experienced before, albeit all of them belonged to the same large pre-1993 municipalities. Naturally, these situations produced centrifugal tendencies as none of them had sufficient gravitational force or economic strength to preserve the unity of their municipality. These cases were especially frequent in economically lagging parts of the country where seceding parts sought an opportunity to improve their conditions by establishing direct connection to national fiscal equalisation schemes by having their own municipality.

Another indication of the importance of the marginalisation argument for the analysed secessions is the surprisingly big share of splits in which only one settlement separated. Croatian municipalities currently comprise approximately 12 settlements on average and there are only $45(8 \%)$ municipalities with only one settlement. Even 26 of them resulted from these splits ( $58 \%$ ), which means that in $40 \%$ of the analysed cases, a single settlement separated from the remaining part of the municipality. The number of settlements in municipalities abandoned by the single settlement varies from one (in two cases) to 32 . In a way, separations of single settlements not only indicate the economic reasoning of marginalised areas, but also show their distinctive identity.

2. Among cultural factors and identity issues, reminiscence of having been their own separate municipality might have some effect, but its importance is difficult to discern. Apart from the last three decades of the communist regime, Croatia traditionally had a rather fragmented local government structure. Arguably all separated municipalities might have invoked a period in which they were an autonomous entity. However, there are at least two circumstances that diminish the relative weight of this factor: a) the most recent cases of separate autonomy preceded these splits for 30-40 years and date back to the pre-1963 period, which brings into question the importance of such a distant memory for modern-day decisions; b) in 1945-55, arguably all current municipalities (including those that seceded) were separate entities, as local government was founded on the extremely large number of basic units, which in 1952 was rationalised to 737 . If a memory of that period played a significant part in explaining these splits, there would be a much bigger number of secession initiatives.

The issue of wrongly drawn borders having connected different identities does not play a major role in Croatian splits. All municipalities involved in splits (new and abandoned) were within the boundaries of the same socialist municipality for at least three decades, so none of them were put together for the first time by the local government reorganisation in 1993. Cultural, linguistic or ethnic/religious differences among municipalities that divorced were and still are almost non-existent. In only one case is there a comprehensive difference in ethnic composition between the new and the abandoned municipality. This is the case of Negoslavci municipality, which has an overwhelming Serb majority that seceded from the municipality of Bogdanovci in 1998.

3. The influence of local political factors on municipal splits in Croatia seems to be of moderate importance, at least according to the indicators that could be obtained. Municipal secessions might be pushed by territorially defined differences in political preference within a municipality. As secession initiatives never have a formal partisan affiliation and there are no voting records for different parts of municipalities on elections that preceded the split, the weight of this factor can be examined only retrospectively. If territorially defined political opposition was decisive for a split, one would expect this circumstance to materialise as different outcomes of local elections following the split in new and abandoned municipalities. However, this difference was manifested in only a minor share of electoral outcomes. In 51 cases $(77 \%)$, the first local elections after the split were won by the same party in both new and abandoned municipalities, and only in 15 cases $(23 \%)$ did the electoral outcome produce different winners. The results of subsequent local elections (the second cycle after the split) show a more divergent picture in 27 cases $(41 \%)$ there is a difference between the new and abandoned municipality regarding the most successful party at local elections. ${ }^{8}$ The interpretation is ambiguous - splits might have deepened the divergence in political preferences between separate municipalities, but at the same time it is possible that this difference might have existed even before and influenced the split more profoundly than the immediate local elections following the split have shown.

\section{Conclusion}

The dynamics of the Croatian case of local government fragmentation do not deviate much from other cases in CEE countries. A favourable political and legislative environment during the early transition period produced a multitude of realised secessions. A common urge was to distance the new state and its institutions from the old regime as radically as possible. In the local government context this meant that fragmentation was not only tolerated but desirable. At the same time, secession initiatives were dealt with in a politically arbitrary manner, without any general guidance or criteria. The analysis has shown the gradual change in both political attitude and formal rules that slowly but steadily closed the window of opportunity for further splits. The absence of new splits coincided with the tightening up of procedural rules. However, the reasons for this are of a

${ }^{8}$ For the purpose of this argument, the winning party in a municipality is indicated by
the relative majority of votes in local council elections. Electoral results are obtained
from the archive of local elections' official results at the national electoral commission website: https://www.izbori.hr/arhiva-izbora/\#/app/home 
more political nature - every government since the beginning of the new century has been under severe public pressure to rationalise the politico-administrative apparatus. A combination of international (EU) pressure and recommendations, critique from the academic community and economic recession decisively contributed to the absence of splits. There have been at least a dozen initiatives in recent years, but none even reached the parliamentary arena.

Despite the arbitrariness and voluntarism behind their emergence, the analysed cases of splits have shown a certain level of common reasoning behind them. To a certain extent all examined types of factors contributed to individual cases of municipal secessions and are helpful in understanding their manifestations. However, the analysed data have given the biggest support to economic considerations having been behind the splits. Economic deprivation in general provided a big push for secessions. Two types of municipalities were susceptible to splits mostly - large municipalities with smaller and more distinctive peripheral parts, and small-to-intermediate rural municipalities with only a few settlements of similar size and importance.
The problem of territorial fragmentation and its consequences have been noticed and discussed extensively over the past two decades. The period of recession and stagnation (2009-14) brought an opportunity not only to debate, but to commence a profound structural reform of the local government system (Koprić, Škarica \& Manojlović 2019). Still, no recent governments have wanted to engage in a process of territorial consolidation. On the other hand, they were equally reluctant to allow further fragmentation. It seems that there is a tacit consensus that the number of municipalities is not to be increased, and preserving the status quo has been the predominant strategy of main political actors and parties in recent years.

\section{ORCID}

Mihovil Škarica (1D) https://orcid.org/0000-0003-0947-132X

\section{References}

Baldersheim, H \& Rose, LE 2010, 'Territorial choice: Rescaling governance in European States' in Territorial Choice: The Politics of Boundaries and Borders, eds. $\mathrm{H}$ Baldersheim \& LE Rose, Palgrave Macmillan, London, pp. 1- 20.

Erlingsson, GO 2005, 'Modelling secessions from municipalities', Scandinavian Political Studies, vol. 28, no. 2, pp. 141-159.

Hrvatski Sabor 2005, Izvješća Hrvatskog Sabora 422 [Report no. 422 of the Croatian Parliament]. Available from: <https:// www.sabor.hr/sites/default/files/uploads/inline-files/5 IHS_422.pdf>. [25 May 2020].

Hrženjak, J 2000, 'Grad Zagreb u sustavu lokalne samouprave u Republici Hrvatskoj' ['The City of Zagreb in the Croatian local government system'], Hrvatska javna uprava, vol. 2, no. 2, pp. 299- 320.

Ivanišević, S 2000, 'Teritorijalna osnova lokalne i regionalne samouprave uz posebni osvrt na položaj Grada Zagreba i njegovu samoupravu' ['Territorial basis of local and regional government with a special consideration to the position of the City of Zagreb'], Hrvatska javna uprava, vol. 2, no. 4, pp. 585-601.

Koprić, I 2010, 'Teritorijalna organizacija Hrvatske: stanje, kriteriji za prosudbu racionalnosti i prijedlog novog sustava' ['Territorial organisation in Croatia: state-of-art, criteria for rationality and proposal of a new system'] in Nova hrvatska lokalna $i$ regionalna samouprava, ed J Barbić, Hrvatska Akademija Znanosti i Umjetnosti, Zagreb, pp. 109- 144.

Koprić, I, Škarica, M \& Manojlović Toman, R 2019, 'Local Public Services and Austerity Measures in Croatia: Adaptations of the Resilient Social Model through the Central-Local Power and Blame Games' in Local Public Services in Times of Austerity across Mediterranean Europe, eds. A Lippi \& TN Tsekos, Palgrave Macmillan, London, pp. 167-191.

Malić, A \& Stiperski, Z 1993, 'Političko-teritorijalni ustroj i centralitet naselja Republike Hrvatske' ['Politico-territorial organisation and the centrality of settlements in the Republic of Croatia'], Acta Geographica Croatica, vol. 28, pp. 67-83.

Ministry of Finance 2020, Financijski izvještaji jedinica lokalne $i$ regionalne samouprave [Financial reports of local and regional government units]. Available from: <https://mfin. gov.hr/istaknute-teme/lokalna-samouprava/financijskiizvjestaji-jlp-r-s/203>. [1 June 2020].
National electoral commission 2020, Lokalni izbori [Local elections]. Available from: <https://www.izbori.hr/arhivaizbora/\#/app/home>. [1 June 2020].

Pavić, Ž 2010, 'Koliko je važna veličina lokalnih jedinica europski primjeri i hrvatski uvjeti' ['How important is the size of local government units? European examples and Croatian context'] in Nova hrvatska lokalna i regionalna samouprava, ed. J Barbić, Hrvatska Akademija Znanosti i Umjetnosti, Zagreb, pp. 85- 108.

Swianiewicz, P 2010, 'Territorial fragmentation as a problem, consolidation as a solution' in Territorial Consolidation Reforms in Europe, ed. P Swianiewicz, Open Society Institute, Budapest, pp. 1-23.

Swianiewicz, P 2021, 'From post-communist democratic laissezfaire to prevention of territorial fragmentation: tightening the rules of municipal splits in Central and Eastern Europe after 1990', Miscellanea Geographica - Regional Studies on Development, vol. 25, no. 1, pp. 5-17.

Swianiewicz, P \& Gendźwiłł, A 2017, Territorial reforms in Europe: Does size matter?, Centre of Expertise for Local Government Reform, Council of Europe. Available from: <https://rm.coe. int/territorial-reforms-in-europe-does-size-matter-territorialamalgamatio/168076cf16>. [01 June 2020].

Škarica, M \& Giljević, T 2016, 'Inter-municipal cooperation in local service provision: Comparative trends and regulatory frameworks' in Good Local Governance: Application of European standards for local public services in France and Croatia, eds. D Lhomme, A Musa \& S De La Rosa, Larcier Bruylant, Bruxelles, pp. 97-122.

Zakon o lokalnoj i područnoj (regionalnoj) samoupravi [Law on local and regional government], Narodne novine [Official Gazzette] no. 33/2001, 60/2001, 129/2005, 109/2007, $125 / 2008, \quad 36 / 2009, \quad 150 / 2011, \quad 144 / 2012, \quad 19 / 2013$, $137 / 2015,123 / 2017,98 / 2019$

Zakon o područjima županija, gradova i općina u Republici Hrvatskoj [Law on territorial areas of the counties, towns and municipalities in the Republic of Croatia], Narodne novine [Official Gazzette], no. 90/1992, 2/1993, 58/1993, 90/1993, 10/1994, 29/1994.

Zakon o područjima županija, gradova i općina u Republici Hrvatskoj [Law on territorial areas of the counties, towns 
and municipalities in the Republic of Croatia], Narodne novine [Official Gazzette], no. 10/1997, 124/1997, 68/1998, 22/1999, 117/1999, 128/1999, 44/2000, 125/2000, 92/2001, 79/2002, 83/2002, 25/2003, 107/2003, 175/2003.

Zakon o područjima županija, gradova i općina u Republici Hrvatskoj [Law on territorial areas of the counties, towns and municipalities in the Republic of Croatia], Narodne novine [Official Gazzette], no. 86/2006, 125/2006, 16/2007, 95/2008, 46/2010, 37/2013, 44/2013, 45/2013, 110/2015.

Žuljić, S 2001, 'Regionalno i teritorijalno ustrojstvo Hrvatske u razdoblju između godina 1945- 2000' [Regional and territorial organisation in Croatia in the 1945- 2000 period], Ekonomski pregled, vol. 52, no. 1-2, pp. 3-28. 